\title{
Q'Professional Contexts for Modern Languages': work experience and academic reflection in a multilingual context
}

\section{Olga Gomez-Cash ${ }^{1}$}

\section{Abstract}

Tn the second year module 'Professional Contexts for Modern Languages' at Lancaster University, students take 20-25 hour placements, and using a multimodal forum, they articulate their challenges, development and understanding of the varying contexts in which they are working. In summative assessment, students across languages and types of activity communicate and learn from each other so as to foster a broad, cross cultural understanding of language-based professional and business contexts (mainly in educational, digital marketing and translation sectors both in the UK and abroad). The module establishes a mutually productive engagement between a university languages department, faculty employability and central careers staff, the Lancaster University Students Union (that source teaching placements) and local and European employers. Inspired by a vision of modern languages degrees as fostering a global mind-set and cultural intelligence, the course allows us to rethink language learning within a framework of skills for employability.

Keywords: skills development, business contexts, cultural intelligence, student placements, multilingual contexts.

\footnotetext{
1. Lancaster University, Lancaster, United Kingdom; o.gomez@lancaster.ac.uk
}

How to cite this chapter: Gomez-Cash, O. (2016). 'Professional Contexts for Modern Languages': work experience and academic reflection in a multilingual context. In E. Corradini, K. Borthwick and A. Gallagher-Brett (Eds), Employability for languages: a handbook (pp. 57-66). Dublin: Research-publishing.net. http://dx.doi.org/10.14705/rpnet.2016.cbg2016.464 


\section{Context and rationale}

Admissions tutors and others who promote studying languages degrees often repeat that language graduates develop a broad range of transferable skills, such as a capacity to deal with people across cultural boundaries, giving them an advantage in the job market. Colleagues who oversee year abroad placements are sure of this too. Language professionals often cite the multilingual nature of contemporary global societies we live in to underscore the importance of language degrees. Much of this discourse refers to by-products of studying languages.

I had participated in a faculty-wide project (Dawes, Fox, \& Gomez-Cash, 2016) focused on the ways in which employability can be integrated into the curriculum. A central principle of the project was a sense of the importance of a subject-specific approach to employability, although we started by considering institutional guidelines on employability and engagement as overarching strategic goals. Employability has of course been defined in our institution, but how it is to be embedded is not explicit. It also became one of our goals to explore ways of expanding notions of employability beyond Destinations of Leavers from Higher Education (DELHE) statistics.

Several employability skills models were reviewed in order to identify 'common' skills across these. Using Cole and Tibby's (2013) Higher Education Authority document 'Defining and developing your approach to employability', we identified employability models such as the CBI and NUS (2011) framework. In addition, we referred to the Lancaster University's skills bank which is used by our Careers Service to highlight the employability skills graduates need to develop. We also considered Jones and Warnock's (2014) competency framework for student work based learning. The skills and competencies identified in these models were mapped onto an employability skills matrix in order to identify commonly occurring skills. We blended the findings with a mapping exercise of the generic skills identified in Quality Assurance Agency's benchmark statements for Humanities disciplines. As a modern linguist, it was reassuring that the general discourse about language degrees is entirely accurate 
and that of the skills that humanities degrees aim to foster, language degrees offer the broadest array of skills.

The employability skills that featured most prominently were:

- communication skills (verbal and written);

- problem-solving;

- team-work;

- self-management;

- computer literacy/IT skills;

- business/commercial awareness;

- numeracy.

Other related skills were:

- adaptability/flexibility;

- ability to work independently;

- decision making;

- planning and organising;

- initiative taking;

- creativity;

- leadership skills; 
- self-awareness;

- analytical/evaluation skills;

- networking;

- cultural sensitivity.

Part of the faculty project was to run a workshop with employers and recent alumni which was firstly designed to interrogate what employers looked for in graduates and secondly, if the skills included in our matrix were the type of skills employers were looking for in graduates. Employer satisfaction was generally high except perhaps in business and customer awareness, a finding similar to that reported in the CBI/Pearson Education and Skills survey (2014). Two skills that are common across the majority of employability skills models but are given little or no importance in the Humanities subject benchmarks are indeed business/commercial awareness and numeracy.

The matter of business awareness may seem a problematic one for a humanities subject: are we expecting to deliver courses looking at individual national contexts and the economy, business, accounting, law and the marketplace? A more productive approach seemed to be to focus on understanding the context that our discipline operates in and how that discipline 'changes shape' when explored via this professional context.

A 'Professional Contexts' approach, therefore, would support students to begin to appreciate and explore, as part of their reflective work placement reports, the financial, business and language policy context of the placements in, for example, local school, commercial language-teaching companies, translation companies, and digital marketing. There are many debates for them to start to engage with, for example, to name a few: what is the status of languages in current educational policy in the UK and abroad? How do professional translators work with translation software? How do multilingual companies engage with various 
languages? What are the challenges for multilingual practice in the digital era? What are the challenges for private language schools?

\section{Aims and objectives}

One of my aims in developing a 'Professional Contexts for Modern Languages' course for second year undergraduates on language and joint language with non-language subject degrees at Lancaster University was to create a course in which skills development via work experience in a multilingual context would be central and indeed, the object of academic reflection.

Developing skills that are valued in the workplace while at university can support an engaged and proactive transition into employment upon graduation. My department of European Languages and Cultures already has a consistent track record of success with regards to graduate employment. It seemed important, institutionally, as mentioned above, to have an academic space that enhanced awareness of this aspect of our languages degrees and supported students to explicitly articulate their development of skills and attributes that enhance employability.

There are also contextual matters of importance to languages that needed to be embedded in the design of the course itself. These are very clearly delineated in the Born Global interim findings (British Academy, 2014), which I will briefly summarise here. Facing head-on the issues of subject identity for languages as a subject (is it an academic discipline or skill?), and given the importance of employability and the interrelatedness of mobility and multilingualism, the report asks a crucial question: can languages be located within a broader matrix of transferable skills? Employers interviewed for Born Global were convinced of the importance of commercial awareness and work experience, in particular applying language skills in 'real world' contexts. Employer satisfaction was generally low for language skills, intercultural awareness as well as business and customer awareness. These skills are all classified as employability skills for 
graduates and this makes the connection between languages and employability a fertile one.

This report's vision of modern languages degrees as fostering a global mind-set and cultural intelligence is an inspiring one. It seemed urgent to forge a module where students were required to develop the skills and attributes that prepare them for multilingual employment and explore their development of linguistic fluency in the target language in a professional context. Following on from this, it seems such a module would also enhance a student's ability to recognise and interpret cultural codes of practice and 'translanguage', and take the first steps in learning to build multilingual professional relationships.

\section{What we did}

One of Lancaster's innovations in language degrees is the successful development of comparative courses that straddle different languages and create coherence by promoting an understanding of European cultures and societies within a global context.

Our second year comparative courses, taken by all students who are on a joint or single major in a language or languages, allow the students to take wideranging courses on the following themes: Language and identity, European economic history, Comparative literature, Cultural theory, and Comparative film studies. The Professional context module became another option amongst these comparative modules. It is a strength then of this module that it is taken by students across languages and this further emphasises the need to make comparisons across a variety of national and linguistic contexts of employment.

In order to formalise the process of taking the module and to start developing our students professionally, short interviews were held in the weeks leading up to module enrolment as well as part of the sourcing of placements. 
The Faculty of Arts and Social Sciences has been creating a bank of generic unpaid work placements to be offered across the faculty for some years. These placements are designed to enhance student employability, but they are also designed to develop an enhanced engagement between our degree schemes (across all our subject areas) and the local business community. The work of sourcing placements, sometimes by the student, languages staff, or the faculty placement officer, is part of the process of engagement and discovery - which local companies can we work with? Which European companies can we work with to find short placements?

The preparation for the module, i.e. the process of preparing and sending CVs, going through Disclosure and Barring Services (DBS) checks, entering in communication with the professionals that they will work with, etc. is already part of the learning and skills development process.

As part of the course, students typically spend between 25-30 hours over a period of 10 weeks engaging with a placement organisation in the second part of the second year. Alternatively, students may undertake a 'block' placement over a two to three week period during the Easter vacation. This option allows students to undertake placements abroad and to work with companies that we have created partnerships with for the Year Abroad.

Students undertaking school placements do so under the auspices of an engagement initiative undertaken by our Students' Union (SU). They thus undertake a volunteer evening training event dealing with issues such as lesson planning, safeguarding and protection during which they engage with professional staff in the SU and teachers from local schools. The SU also finances checks.

The academic reflection begins in two seminars at the start of the course by getting students to use self-evaluation tools to become aware of their starting point. Online psychometric testing is available via the University Careers service. Although the tests are done in English, the software does provide some 
alternatives in the languages we deliver at Lancaster (French, German, Italian and Spanish). This is a first step in identifying the attributes they have and those which they need to develop. A self-audit of the key skills that students should be developing through their degree provides another tool in which students can start to articulate their development needs in an e-portfolio. A workshop on employability skills led by University Careers staff allows students to articulate their findings from the tools exploring their attributes, skills and readiness for employability and discuss these with each other. Students are encouraged to take an array of central career development workshops (on using LinkedIn, on networking...) and reflect on them.

Alongside their placements, formative assessment in the shape of an e-log book encourages students to gather up these reflections and articulate their development and understanding of the varying business and policy contexts they are working in. Using this multimodal forum, students develop narratives and visualisations of working in a language based context that explore and reinforce the skills they have identified they need to develop. In one mid-term session, formative feedback is also provided on initial drafts of and ideas for the reflective report. My experience is that this is the most difficult part for the students, and that support is needed for them to able to frame their experience in a context and 'theorise' it.

The project report asks students to explore a maximum of three features of the business and policy contexts they worked in. They can reflect on working in and with languages, and related cross-cultural issues assess issues of communicating across cultures/languages and critically reflect on how their linguistic and cultural knowledge can be applied in the workplace environment. This is submitted at the end of the placement and gives students the opportunity to discuss and reflect on key issues they have identified that relate to their placement organisation and its context. Summative assessment is provided with the end-of-module presentation where students across languages and types of activity communicate and learn from each other in so as to also foster a broad, cross cultural understanding of language-based professional and business contexts. 


\section{Discussion and conclusion}

The focus on reflective learning on cross cultural environments makes the module a useful preparation for the year abroad and, in due course, I hope it will inform a more nuanced understanding of what might be a recognition framework for linguistic and intercultural competence.

Very importantly, the course also establishes a mutually productive engagement between staff in a university languages department, faculty employability, central careers, the Lancaster University Students Union, and local and European companies with a language focus. We hope to strengthen these ties by building innovative and interdependent relationships that inform and stimulate research and teaching on the 'real world' contexts of Modern Languages.

To return to the faculty-wide project that kick-started this module, it is important that this module works in a supportive academic context. To enhance employability across the faculty, we have a Faculty Employability Forum whose primary focus is on information sharing on new developments in the faculty. We have had workshops to ensure robust preparation for academic reflective practice, and it is envisaged that some work on academic reflection and the different ways in which departments in the faculty embed skills into the curriculum will continue to be shared and discussed. This way, we would ensure the development of a variety of innovative assessments and to collate and build understanding of needs of, for example, professional bodies relevant to students across the many disciplines that languages work with productively.

It is also envisaged for the coming academic year that this module will be taken by visiting international students to Lancaster University. We have a new Erasmus agreement with a University Education Studies department in Spain that will provide both teacher training modules and short teaching placements for Lancaster students. In return, Spanish students will be able to take the 'Professional Contexts' module and take part in language teaching support in local schools. Given the language needs of local schools, this seems on course to be a fruitful development. It has brought the possibility of opening 
up the module to Erasmus students from all over Europe and integrating them in a programme of learning that can truly deliver what this course seeks: to bring together multilingual communication skills, international intercultural awareness, and business and customer awareness.

\section{Acknowledgements}

Many thanks to various staff across Lancaster University: Frank Dawes, Kate Dunbavan, Sarah Fox, Chris May and Charlotte Stuart for their collaboration on the FASS/HEA 'Embedding employability' project and their support in thinking through work-based learning. In particular, I am grateful to Frank and his invaluable work on mapping and modelling employability skills.

\section{References and links}

CBI/NUS. (2011). Working towards your future: making the most of your time in higher education. London: CBI. Retrieved from http://www.nus.org.uk/Global/CBI_NUS_ Employability\%20report_May\%202011.pdf

CBI/Pearson education and skills survey. (2014). Gateway to growth. Retrieved from http:// www.cbi.org.uk/media/2807987/gateway-to-growth.pdf

Cole, D., \& Tibby, M. (2013). Defining and developing your approach to employability: a framework for higher education institutions. The Higher Education Academy.

Dawes, F., Fox, S., \& Gomez-Cash, O. (2016). Developing a flexible framework for embedding work-based modules in the curriculum. Faculty of Arts and Social Sciences, Lancaster University. York: HEA. Retrieved from https://www.heacademy.ac.uk/resource/ developing-flexible-framework-embedding-work-based-learning-modules-curriculum

Jones, H. M., \& Warnock, L. (2014). Towards a competency framework for student work based learning. The Higher Education Academy.

The British Academy. (2014). Interim findings of the Born Global research project. Retrieved from http://www.britac.ac.uk/policy/Born_Global.cfm 


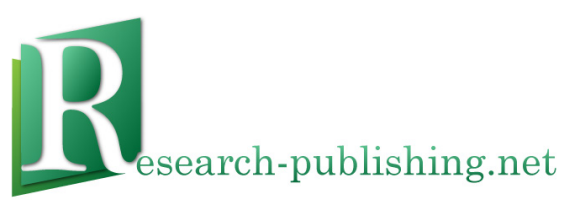

Published by Research-publishing.net, not-for-profit association Dublin, Ireland; Voillans, France, info@research-publishing.net

(C) 2016 by Erika Corradini, Kate Borthwick, and Angela Gallagher-Brett (collective work)

(C) 2016 by Authors (individual work)

Employability for languages: a handbook

Edited by Erika Corradini, Kate Borthwick, and Angela Gallagher-Brett

Rights: All articles in this collection are published under the Attribution-NonCommercial -NoDerivatives 4.0 International (CC BY-NC-ND 4.0) licence. Under this licence, the contents are freely available online as PDF files (http://dx.doi.org/10.14705/rpnet.2016.cbg2016.9781908416384) for anybody to read, download, copy, and redistribute provided that the author(s), editorial team, and publisher are properly cited. Commercial use and derivative works are, however, not permitted.

\section{(9) $\Theta \Theta \Theta$}

Disclaimer: Research-publishing.net does not take any responsibility for the content of the pages written by the authors of this book. The authors have recognised that the work described was not published before, or that it was not under consideration for publication elsewhere. While the information in this book are believed to be true and accurate on the date of its going to press, neither the editorial team, nor the publisher can accept any legal responsibility for any errors or omissions that may be made. The publisher makes no warranty, expressed or implied, with respect to the material contained herein. While Research-publishing.net is committed to publishing works of integrity, the words are the authors' alone.

Trademark notice: product or corporate names may be trademarks or registered trademarks, and are used only for identification and explanation without intent to infringe.

Copyrighted material: every effort has been made by the editorial team to trace copyright holders and to obtain their permission for the use of copyrighted material in this book. In the event of errors or omissions, please notify the publisher of any corrections that will need to be incorporated in future editions of this book.

Typeset by Research-publishing.net

Cover design and frog picture by (C) 2016 Raphaël Savina (raphael@savina.net)

Cover illustration by (C) 2016 Nicolas Fenix (www.nicolasfenix.com)

ISBN13: 978-1-908416-37-7 (Paperback - Print on demand, black and white)

Print on demand technology is a high-quality, innovative and ecological printing method; with which the book is never 'out of stock' or 'out of print'.

ISBN13: 978-1-908416-38-4 (Ebook, PDF, colour)

ISBN13: 978-1-908416-39-1 (Ebook, EPUB, colour)

Legal deposit, Ireland: The National Library of Ireland, The Library of Trinity College, The Library of the University of Limerick, The Library of Dublin City University, The Library of NUI Cork, The Library of NUI Maynooth, The Library of University College Dublin, The Library of NUI Galway.

Legal deposit, United Kingdom: The British Library.

British Library Cataloguing-in-Publication Data.

A cataloguing record for this book is available from the British Library.

Legal deposit, France: Bibliothèque Nationale de France - Dépôt légal: juin 2016. 